\title{
Evolutionary systematic of three species of troglobitic beetles: electrophoretic and morphological evidence
}

\author{
B Crouau-Roy* \\ ${ }^{1}$ Laboratoire souterrain du CNRS, Moulis, 09200 Saint-Girons, France
}

(Received 29 September 1988; accepted 17 January 1990)

\begin{abstract}
Summary - Genic and morphological variations were compared for 3 allopatric and endemic troglobitic beetles of the genus Speonomus, by use of an allozyme data set (18 putative loci) and 1 based on morphometric characters (16 morphological variables). Allozymic and morphometric relationships were also compared with some aspects of the mating behaviour, and considered in relation to the ecology and biogeography of these species. The extent of agreement between the assessments of evolutionary divergence at the genic and morphological levels is discussed. Enzyme analysis revealed pronounced differences in degree of genetic differentiation between the 3 species: $S$ colluvii is the most divergent species with large genetic distances $(D \simeq 1)$. Morphometric differentiation between the 3 species, assessed on 16 characters, is important between the 3 species, principally between $S$ zophosinus and the 2 others. The level of congruence is strongly data - set dependent and these results reveal independent trends for the 2 sets of characters. While $S$ zophosinus has diverged little from $S$ hydrophilus on the molecular level, the morphometric differentiation between them is high. This pattern may result from different sensitivities of each character set to different components of the environment.
\end{abstract}

troglobitic beetle / systematic / electrophoretic and morphometric variations

Résumé - Systématique évolutive de trois espèces de Coléoptères troglobies: analyses électrophorétiques et morphologiques. Nous avons comparé les variations génétiques et morphologiques de trois espèces de Coléoptères troglobies allopatriques et endémiques du genre Speonomus sur la base des données allozymiques (18 locus) et des caractères morphométriques (16 variables). Les distances basées sur les données génétiques et les divergences morphologiques et biométriques sont également comparées à certains aspects du comportement lors de l'accouplement et discutées en fonction du contexte écologique et des caractéristiques biogéographiques de ces espèces. L'analyse des locus, correspondant à 19 protéines enzymatiques, met en évidence des différenciations importantes entre ces espèces: S colluvii est l'espèce la plus divergente avec une distance génétique voisine de 1 . $L$ 'étude morphométrique estimée sur 16 caractères sépare les populations des trois espèces selon la largeur du pronotum et la longueur des élytres (S zophosinus les plus petits, $\mathrm{S}$ hydrophilus les plus grands), la largeur des articles antennaires et la forme $d u{ }^{e}$ article antennaire. Il n'y a pas concordance entre les données moléculaires (gènes structuraux) et morphométriques: $\mathrm{S}$ zophosinus sur le plan moléculaire a peu divergé de $\mathrm{S}$ hydrophilus

*Present address: Centre de Recherches sur le Polymorphisme Génétique, des Populations Humaines (CRPG) - CNRS, CHU Purpan, Avenue de Grande-Bretagne, 31300 Toulouse, France 
alors que la différenciation morphométrique est importante entre ces espèces. L'action différentielle des pressions de sélection aux différents niveaux, protéique et morphologique, peut rendre compte de ces discordances.

coléoptère troglobie / systématique / variations électrophorétiques et morphométriques

\section{INTRODUCTION}

Closely related species provide opportunities to study how the evolutionary process operates in natural populations. Nevertheless, it is often difficult to assign taxonomic ranks or to reconstruct phylogenetic relationships. A high degree of independence is often observed between molecular and morphological evolution (Gorman and Kim, 1976; Sene and Carson, 1977; Schnell et al, 1978; Turner et al, 1979; Lessios, 1981; Berlocher and Bush, 1982; Allegrucci et al, 1987); this may be due to varying selection pressures on different traits (Turner et al, 1979) or merely related to the number of loci segregating for the different characters (Lewontin, 1984). Electrophoretic separation of enzymes has become a powerful tool for investigating systematic and evolutionary problems (Avise, 1974). Morphological studies alone are usually inadequate to determine evolutionary relationships in closely related species. Integrative studies utilizing allozyme variability and data from behavioural breeding systems in addition to morphometric variability are most powerful in such complex groups; then we can estimate the importance of gene flow, genetic drift and selection in shaping population structures.

The 3 species of Bathysciinae (Coleoptera) of this study belong to a monophyletic group of the genus Speonomus which contains many cave-dwelling species from the more primitive to the more specialized (Jeannel, 1924). Studies on these species have been the subject of repeated analyses by various approaches, including the study of morphology (Jeannel, 1924; Juberthie et al, 1980a; Juberthie et al, 1981; Delay et al, 1983), karyology (Durand and Juberthie-Jupeau, 1980) and allozymic variation (Crouau-Roy, 1989a, b). The relationship of these beetles to one another and to other species groups of Speonomus has not been adequately resolved. The 3 allopatric species $S$ hydrophilus, $S$ zophosinus and $S$ colluvii, narrowly endemic to central Pyrenees (fig 1), have undergone some ecological divergence and present a high degree of specialization to underground life ( $\mathrm{eg}$ life cycle of 1 larval stage with suppression of larval feeding, Deleurance-Glaçon, 1963). These blind and wingless troglobitic species occur in caves and deep soil (Juberthie et al, 1980a, b) in the massif Arize ( $S$ hydrophilus at about $430-1440 \mathrm{~m}$ ), in the valleys of Salat and Arac rivers ( $S$ zophosinus at about $480-620 \mathrm{~m}$ ) and on the north face of the massif des Trois Seigneurs $(S$ colluvii at about $700 \mathrm{~m}-1350 \mathrm{~m}$ ) at the foothill of the French central Pyrenees. The southern extent of the massif Arize (between the area of $S$ hydrophilus and $S$ zophosinus) is composed of colmated metamorphic rocks which seem to be geological barriers to underground colonization by cave fauna. Their distribution strongly suggests that speciation occurred after gene flow was interrupted by physical barriers: there were probably geomorphological and pedological barriers after climatic shifts during the ice ages and interglacials of the quaternary. 


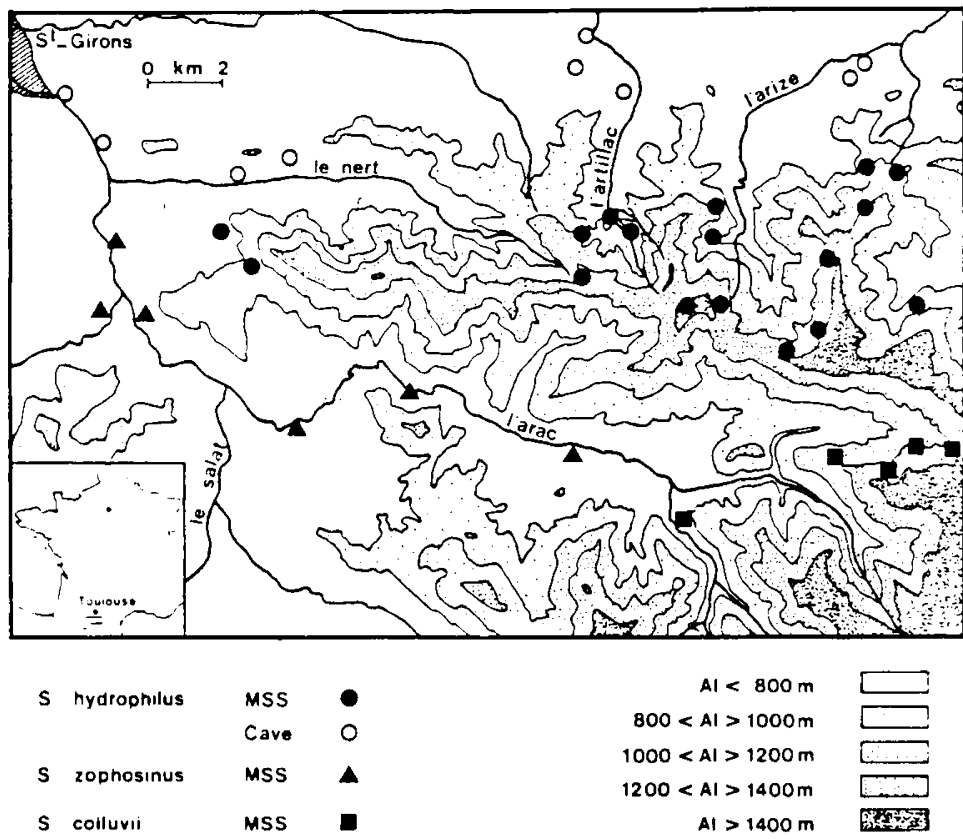

Fig 1. Geographical location of sampled populations for the electrophoretic and the morphometric study (Map of the distribution of the 3 species of Speonomus with the sample sites).

The phylogeny of these 3 closely related troglobitic (ie, obligate cave dwelling) beetles was investigated using isozyme electrophoresis and biometric analysis. Patterns of allozyme and biometric variation were compared with some aspects of the mating behaviour and aspects of the ecology of these organisms to address the question of intrageneric relationships of species within this group of beetles.

The present study provides answers to the following questions: 1) how much genetic variation is contained in these populations? 2) how is the genetic variation partitioned within and among the isolated populations? 3) what phylogenetic relationships can be deduced from the isozyme data and how congruent are they with biometrical based relationships at the species level? 4) how do the different approaches contribute to our knowledge of evolution in this group?

\section{MATERIALS AND METHODS}

Twenty-three populations of $S$ hydrophilus, 6 of $S$ zophosinus and 5 of $S$ colluvii were studied for electrophoretic, morphometric and behavioural studies.

\section{Electrophoretic analyses}

Electrophoresis was performed in slabs of $12 \%$ hydrolized starch for the following enzymes: esterases (Est-1, Est-6, EC 3.1.1.2), alkaline phosphatase (Aph, EC 3.1.3.1), 
leucine aminopeptidase (Lap-1, EC 3.4.11.1), malic enzyme (Me, EC 1.1.1.40) hexokinases (Hk-1, Hk-3, Hk-4, EC 2.7.1.1) phosphohexose isomerase (Phi-1, Phi-2, EC 5.3.1.9) and $\alpha$ glycero-phosphate dehydrogenase ( $\alpha$-Gpdh, EC 1.1.1.8); in slabs of acrylamide for fumarase (Fum, EC 4.2.1.12), hydroxybutyrate dehydrogenase (Hbdh-1, Hbdh-2, EC 1.1.1.30), acid phosphatase (Pac-1, EC 3.1.3.2) malate dehydrogenase (Mdh, EC 1.1.1.37), and lactate dehydrogenase (Ldh, EC 1.1.1.28), aldehyde oxidase (Ao, EC 1.2.3.1). Additional loci that could not be scored unequivocally were deleted from further analysis. Loci and alleles were numbered, respectively, in order of decreasing anodal migration. Electrophoresis buffers and stains are described in Crouau-Roy (1986). Individuals from different species were run together on the same gel to determine whether corresponding electromorphs had similar mobilities. Allozyme frequencies for each sample were derived from the electrophoretic results. These data were employed to compute genetic distance estimates (Nei, 1972, 1978) which were used for a phenetic averaging (UPGMA; Sneath and Sokal, 1973). The apportionment of genetic diversity was determined using genetic diversity analysis (Wright, 1965; Nei, 1977, 1986). Total gene diversity ( $H_{T}=1-\Sigma x_{1}^{2}$ : weighted average allele frequencies over all populations) is subdivided into gene diversity within populations $\left(H_{s}\right.$ : weighted average over all populations of the values $1-\Sigma x_{i}^{2}$ for each population) and gene diversity among populations. Differentiation among populations is calculated as $\left.F_{S T}=H_{T}-H_{S}\right) / H_{T}$.

\section{Morphometric analysis}

Sample sizes for all morphological analyses were 30 adults per population. For $S$ hydrophilus only 18 populations out of the 23 were examined. The following 16 morphological variables were measured from each specimen: length (L) and width (W) of 7 antennal segments $(5 \mathrm{th}, 6 \mathrm{th}, 7 \mathrm{th}, 8 \mathrm{th}, 9 \mathrm{th}, 10 \mathrm{th}$ and length only of the $11 \mathrm{th}$ ), length of the tibia of the 3rd pair of legs (LT), length of the elytra (LE) and width of the pronotum (WP). Measurements were recorded in micrometres. Because of statistically significant correlations between values for the sexes, the measurements were only made in males. Euclidean distances were calculated on the basis of the 16 morphometric variables; a dendrogram was drawn up using these distances, according to the UPGMA method of cluster analysis (Sneath and Sokal, 1973). Data were also analyzed using a principal components analysis (PCA) on the standardized variables.

\section{RESULTS}

\section{Electrophoretic differentiation}

\section{Genetic structure of populations at enzyme loci}

The allele frequencies for each putative locus (18 loci) are given in table I. Each locus containing more than 1 variant was considered polymorphic. Fourteen of these were polymorphic (Est-6, Lap-1, Phi-1, Phi-2, Pac-1, Hk-3, Hk-4, Hbdh-1, $\mathrm{Me}, \mathrm{Mdh}, \alpha$-Gpdh, Ldh-2, Fum, Ao) and the remaining 4 were monomorphic with the same electromorph fixed in all populations of the 3 species (Hbdh-3, Aph, 
Table I. Gene frequencies for loci coding for monomorphic and/or polymorphic proteins within each species of Speonomus. $N$ is the number of beetles sampled. Anodal mobilities relative to the common allele (termed 100) are used for allozyme nomenclature.

* Monomorphic loci among the 3 species: $A p h, H b d h-3, E s t-1$ and $H k-1$.

\begin{tabular}{|c|c|c|c|c|}
\hline \multicolumn{2}{|c|}{ Loci $^{*}$} & \multirow{2}{*}{$\begin{array}{l}S \text { hydrophilus } \\
\text { (23 localities) } \\
-\end{array}$} & \multirow{2}{*}{$\begin{array}{c}\begin{array}{c}S \text { zophosinus } \\
(6 \text { localities })\end{array} \\
0.354\end{array}$} & \multirow{2}{*}{$\begin{array}{c}S \text { colluvii } \\
(5 \text { localities }\end{array}$} \\
\hline \multirow{13}{*}{ Est-6 } & 84 & & & \\
\hline & 86 & - & 0.126 & - \\
\hline & 88 & - & 0.046 & - \\
\hline & 90 & - & 0.217 & - \\
\hline & 92 & - & 0.231 & - \\
\hline & 94 & 0.004 & 0.029 & - \\
\hline & 96 & 0.011 & - & 0.463 \\
\hline & 98 & 0.085 & - & 0.514 \\
\hline & 100 & 0.473 & - & 0.022 \\
\hline & 102 & 0.196 & - & - \\
\hline & 104 & 0.192 & - & - \\
\hline & 106 & 0.038 & - & - \\
\hline & $\mathrm{N}$ & 2053 & 844 & 252 \\
\hline \multirow{5}{*}{ Lap-1 } & 98 & 0.020 & - & - \\
\hline & 100 & 0.732 & 0.781 & 0.381 \\
\hline & 102 & 0.088 & 0.219 & 0.619 \\
\hline & 104 & 0.160 & - & - \\
\hline & $\mathrm{N}$ & 1447 & 648 & 257 \\
\hline \multirow{6}{*}{ Phi-1 } & 96 & - & 0.857 & - \\
\hline & 98 & 0.004 & 0.143 & 0.741 \\
\hline & 100 & 0.450 & - & 0.259 \\
\hline & 102 & 0.463 & - & - \\
\hline & 104 & 0.083 & - & - \\
\hline & $\mathbf{N}$ & 2074 & 511 & 211 \\
\hline \multirow{5}{*}{ Hk-3 } & 98 & 0.002 & - & - \\
\hline & 100 & 0.986 & 1 & 0.112 \\
\hline & 102 & 0.013 & - & 0.495 \\
\hline & 104 & - & - & 0.393 \\
\hline & $\mathrm{N}$ & 1327 & 560 & 259 \\
\hline \multirow{4}{*}{ Hk-4 } & 100 & 0.994 & 1 & 0.090 \\
\hline & 102 & 0.006 & - & 0.796 \\
\hline & 104 & - & - & 0.114 \\
\hline & $\mathrm{N}$ & 1315 & 560 & 270 \\
\hline \multirow{6}{*}{$\mathrm{ME}$} & 96 & - & - & 1 \\
\hline & 98 & 0.004 & 0.054 & - \\
\hline & 100 & 0.979 & 0.946 & - \\
\hline & 102 & 0.014 & - & - \\
\hline & 104 & 0.004 & - & - \\
\hline & $\mathbf{M}$ & 1467 & 672 & 212 \\
\hline \multirow{4}{*}{$\alpha-\mathrm{Gpdh}$} & 96 & - & - & 0.638 \\
\hline & 98 & - & - & 0.362 \\
\hline & 100 & 1 & 1 & - \\
\hline & $\mathrm{N}$ & 1301 & 422 & 206 \\
\hline
\end{tabular}


Table I. continued

\begin{tabular}{|c|c|c|c|c|}
\hline \multicolumn{2}{|c|}{ Loci ${ }^{*}$} & \multirow{2}{*}{$\begin{array}{c}S \text { hydrophilus } \\
\text { (23 localities) }\end{array}$} & \multirow{2}{*}{$\begin{array}{c}S \text { zophosinus } \\
\text { (6 localities) }\end{array}$} & \multirow{2}{*}{$\frac{\begin{array}{c}S \text { colluvii } \\
(5 \text { localities })\end{array}}{-}$} \\
\hline \multirow{5}{*}{$\mathrm{MDH}$} & 100 & & & \\
\hline & 102 & - & 1 & - \\
\hline & 104 & - & - & 0.574 \\
\hline & 106 & - & - & 0.426 \\
\hline & $\mathrm{N}$ & 1187 & 306 & 263 \\
\hline \multirow{4}{*}{ Pac-1 } & 98 & 0.010 & 0.989 & - \\
\hline & 100 & 0.990 & 0.011 & - \\
\hline & 102 & - & - & 1 \\
\hline & $\mathbf{N}$ & 1352 & 394 & 250 \\
\hline \multirow{3}{*}{ Hbdh-1 } & 100 & 1 & 1 & - \\
\hline & 102 & - & - & 1 \\
\hline & $\mathbf{N}$ & 921 & 240 & 200 \\
\hline \multirow{3}{*}{ Fum } & 100 & 1 & 1 & - \\
\hline & 102 & - & - & 1 \\
\hline & $\mathrm{N}$ & 988 & 238 & 203 \\
\hline \multirow{4}{*}{ Ao } & 100 & 1 & - & - \\
\hline & 102 & - & 1 & - \\
\hline & 104 & - & - & 1 \\
\hline & $\mathrm{N}$ & 920 & 240 & 203 \\
\hline \multirow{3}{*}{ Ldh-2 } & 100 & 1 & - & - \\
\hline & 102 & - & 1 & - \\
\hline & 104 & - & - & 1 \\
\hline \multirow{5}{*}{ Phi-2 } & $\mathrm{N}$ & 920 & 244 & 200 \\
\hline & 98 & - & - & 1 \\
\hline & 100 & 1 & - & - \\
\hline & 102 & - & 1 & - \\
\hline & $\mathbf{N}$ & 2050 & 500 & 211 \\
\hline
\end{tabular}

Est-1, Hk-1). Six loci (Mdh, Hbdh-1, Fum, Ao, Ldh-2 and Phi-2) are diagnostic for at least 1 species, and 2 additional loci (Est-6, Pac-1) are diagnostic with a $1 \%$ probability of error. Estimates of the proportion of polymorphic loci per population (P) and the average frequency of heterozygous loci per individual $(\mathrm{H})$ indicate some differences in genetic variability between the 3 species. Speonomus colluvii displays the highest overall percentage of polymorphic loci $(41.2 \%)$. For the other 2, percent polymorphic loci are $23.0 \%$ in $S$ hydrophilus and $25.5 \%$ in $S$ zophosinus. Expected average heterozygosities, $H_{e x p}$, are listed in table II. Genotypic frequencies are 
compared to expected Hardy-Weinberg proportions by $\chi^{2}$ or $G$-test (Sokal and Rohlf, 1969); $\chi^{2}$ or $G$ values show significant differences between observed genotypic frequencies and those expected under Hardy-Weinberg equilibrium. The genotypic fixation index (Wright, 1965), which measures the relative difference between expected $\left(H_{e x p}\right)$ and observed $\left(H_{o b s}\right)$ heterozygosity, shows a significant deficiency of heterozygotes $\left(F_{I S}>0\right)$ (table II) (Crouau-Roy, 1988).

Table II. $F$-statistics and heterogeneity $\chi^{2}$ values for the 3 species of Speonomus. ns: non significative; ${ }^{*}: P<0.01$. S hydrophilus: $P=0.230(0.015) ; H_{o b s}=0.062(0.014) ; H_{\text {exp }}=$ $0.107(0.029)$.; $S$ zophosinus: $P=0.255(0.012) ; H_{\text {obs }}=0.054(0.006) ; H_{\text {exp }}=$ $0.088(0.008)$; $S$ colluvii $P=0.412(0.000) ; H_{o b s}=0.097(0.002) ; H_{\text {exp }}=0.184(0.004)$.

\begin{tabular}{lccccccccc}
\hline & Est-6 & Lap-1 & Phi-1 & $M e$ & $P a c-1$ & $H k-3$ & $H k-4$ & $\alpha-G p d h$ & $M d h$ \\
\hline$S$ hydrophilus & & & & & & & & \\
$F_{I S}$ & 0.409 & 0.365 & 0.405 & 0.520 & 0.447 & 0.456 & 0.545 & - & - \\
$F_{I T}$ & 0.556 & 0.497 & 0.452 & 0.542 & 0.475 & 0.492 & 0.582 & - & - \\
$F_{S T}$ & 0.249 & 0.208 & 0.080 & 0.047 & 0.052 & 0.068 & 0.083 & - & - \\
$\chi^{2}$ & $1022.4^{*}$ & $601.9^{*}$ & $347.8^{*}$ & $137.9^{*}$ & $140.3^{*}$ & $192.7^{*}$ & $218.3^{*}$ & - & - \\
$S$ zophosinus & & & & & & & & \\
$F_{I S}$ & 0.351 & 0.481 & 0.428 & 0.403 & 0.497 & - & - & - & - \\
$F_{I T}$ & 0.581 & 0.483 & 0.430 & 0.403 & 0.518 & - & - & - & - \\
$F_{S T}$ & 0.354 & 0.005 & 0.004 & 0 & 0.043 & - & - & - & - \\
$\chi^{2}$ & $597.5^{*}$ & $6.5 \mathrm{~ns}$ & $4.1 \mathrm{~ns}$ & $0 \mathrm{~ns}$ & $30.4^{*}$ & & & & \\
$S$ colluvii & & & & & & & & \\
$F_{I S}$ & 0.367 & 0.486 & 0.442 & - & - & 0.443 & 0.385 & 0.507 & 0.468 \\
$F_{I T}$ & 0.379 & 0.546 & 0.448 & - & - & 0.449 & 0.485 & 0.539 & 0.477 \\
$F_{S T}$ & 0.019 & 0.118 & 0.012 & - & - & 0.012 & 0.164 & 0.006 & 0.018 \\
$\chi^{2}$ & $4.7 \mathrm{~ns}$ & $38.5^{*}$ & $4.5 \mathrm{~ns}$ & & & $4.9 \mathrm{~ns}$ & $61.6^{*}$ & $2.2 \mathrm{~ns}$ & $6.8 \mathrm{~ns}$ \\
\hline
\end{tabular}

\section{Genetic differentiation between populations}

The genetic differentiation within the Speonomus species complex was determined using genetic diversity analysis (F-statistics: Wright, 1965; Nei, 1977, 1986) and a $\chi^{2}$ contingency analysis of heterogeneity (Workman and Niswander, 1970). Nire loci are variable in some or all populations of each species (table II). Significant heterogeneity in gene frequencies $\chi^{2}$ was observed among $S$ hydrophilus populations at all variable loci. Significant heterogeneity in allele frequencies was observed among populations of $S$ zophosinus (only at the Est-6 locus). For $S$ colluvii, 2 variable loci (Lap-1 and Hk-4) show significant heterogeneity. There is significant genetic variation between populations in the complex of 3 species (table III). Genetic diversity for 5 loci is due totally to the between-species component $\left(F_{S T}\right)=1$; populations fixed for different alleles: Hbdh-1, Fum, Ao, LDh-2 and Phi-2). For 3 additional loci (Mdh, Pc-1, Me) almost all the diversity is due to between-species variation rather than within-species variation $\left(F_{S T}=0.978,0.979\right.$ and 0.902 , respectively). The mean of 0.790 (for polymorphic loci only) for differentiation 
Table III. Genetic diversity among populations in the species complex of speonomus $F_{T}=$ total heterozygosity, $H_{S}$ : average heterozygosity per population, $F_{S T}$ : fixation index.

*Values are given only for polymorphic loci.

\begin{tabular}{lllc}
\hline & \multicolumn{3}{c}{ Differentiation among populations } \\
Locus & $H_{T}$ & $H_{S}$ & $F_{S T}=\left(\frac{H_{T}-H_{S}}{H_{T}}\right)$ \\
\hline Est-6 & & & 0.409 \\
Lap-1 & 0.857 & 0.506 & 0.266 \\
Phi-1 & 0.502 & 0.366 & 0.482 \\
Hk-3 & 0.751 & 0.389 & 0.574 \\
Hk-4 & 0.465 & 0.198 & 0.769 \\
Me & 0.445 & 0.103 & 0.902 \\
Gpdh & 0.478 & 0.047 & 0.698 \\
Mdh & 0.497 & 0.150 & 0.978 \\
Pac-1 & 0.722 & 0.160 & 0.979 \\
Fum & 0.667 & 0.014 & 1.000 \\
Ao & 0.446 & 0 & 1.000 \\
Hbdh-1 & 0.667 & 0 & 1.000 \\
Ldh-2 & 0.446 & 0 & 1.000 \\
Phi-2 & 0.667 & 0 & 0.790 \\
Mean & 0.667 & 0 & \\
\hline
\end{tabular}

among species indicates that a large portion of the genetic variability in Speonomus is not present among the individuals of a single species.

Extensive isozyme divergence between species is further indicated by their low Nei genetic identity values.

Nei's standard genetic distances corrected for sample size between the populations of each species are listed in table IV. Variances of Nei's distances (Nei and Roychoudhury, 1974) were all on the order of $1.7 \%-2.5 \%$ of the distance values. Beetles from the 3 species are well differentiated: coefficients of genetic distance range between 1.021 and 0.400 . The genetic differentiation observed between the species $S$ hydrophilus and $S$ zophosinus is significant $(D=0.431)$ compared to that observed within each of them (intraspecific values of Nei's index: 0.036 and 0.050 respectively). $S$ zophosinus differed completely from $S$ hydrophilus at 5 isozyme loci (Mdh, Ao, Ldh-2, Phi-2, Est-6) and differed substantially at 2 others (Phi-1, pac-1). The distribution of the loci with respect to genetic identity exhibits the $U$-shaped pattern characteristic of comparisons between good species. Of 18 loci, most are either identical in their allelic composition $(55 \%)$ or completely different $(32 \%$ of its loci are diagnostic for the other). For $S$ colluvii, the genetic differentiation from the other 2 species is greater and affects an important part of the genome $(50 \%$ of its loci are diagnostic: Ao, Fum, Pac-1, Me, Mdh, Hbdh-1, Ldh-2, $\alpha$-Gpdh, Phi-2). The genetic distances between pairs of populations are summarized in figure 2 in the form of a dendrogram by using the UPGMA clustering method: this analysis of the data indicates the pattern of phenetic clustering of the species into 3 major groups. 
Table IV. Nei's standard genetic distance (below the diagonal) based on allozymic variables and Euclidean distances (above the diagonal) based on morphometric variables. Values in parentheses are standard errors.

\begin{tabular}{lccc}
\hline & $\begin{array}{c}\text { S hydrophilus } \\
\text { (23 populations) }\end{array}$ & $\begin{array}{c}\text { S zophosinus } \\
\text { (6 populations) }\end{array}$ & $\begin{array}{c}\text { S colluvii } \\
\text { (2 populations) }\end{array}$ \\
\hline$S$ hydrophilus & - & $263.09(5.68)$ & $116.70(5.82)$ \\
$S$ zophosinus & 0.430 & - & $187.55(16.47)$ \\
$S$ colluvii & 1.002 & 1.020 & - \\
Mean Nei's distance & 0.036 & 0.050 & 0.014 \\
Mean Euclidean distance & $54.33(1.71)$ & $76.70(10.09)$ & $71.99(0.00)$ \\
\hline
\end{tabular}
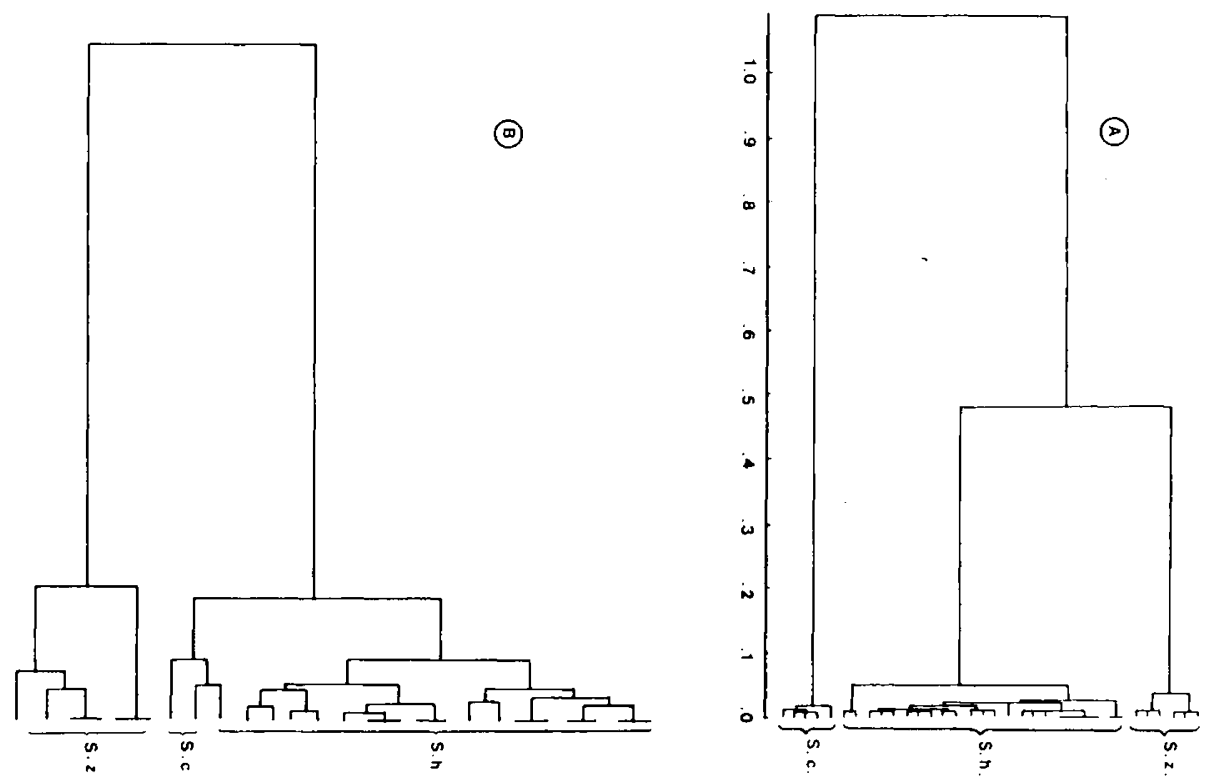

Fig 2. Comparison of the results of the allozymic (A: Nei's genetic distances) and morphometric analysis (B: Euclidean distances) of the 3 species of Speonomus, using the UPGMA clustering method. $S z, S$ zophosinus; $S h, S$ hydrophilus; $S c S$ colluvii.

\section{Morphometric differentiation}

The average values for the 16 morphological characters are given in table $\mathrm{V}$ and relationships between populations of the 3 species have been tested by a Student test. The $S$ hydrophilus and $S$ zophosinus populations display significant differences for all measured morphological characters; between $S$ hydrophilus and $S$ colluvii, 4 comparisons are significant (L8, L7, L6, L5) and only 2 are significant (L11, W9) between $S$ zophosinus and $S$ colluvii. In particular, the shape of the 8th antennal segment (L8 and W8) differentiates the 3 species from each other (fig 3). 
Table V. Average values of 16 biometrical traits for the troglobitic beetles and comparison by a $t$-test of populations coming from different species. Units for all measurements are micrometres. ${ }^{* * *} p \leq 0 .{ }^{* *} p \leq 0.0001$. ( $)^{a}$ : degrees of freedom.

\begin{tabular}{|c|c|c|c|c|c|c|c|c|c|}
\hline \multirow{2}{*}{$\begin{array}{l}\text { Character } \\
\text { WP }\end{array}$} & \multicolumn{4}{|c|}{ S Hydrophilus $\underset{\text { (Standard error) }}{\text { S zophosinus }}$} & \multicolumn{2}{|c|}{ S colluvii } & \multirow{2}{*}{$\frac{\begin{array}{c}\text { Hyd zop } \\
(22)^{a}\end{array}}{8.24^{* *}}$} & \multirow{2}{*}{$\frac{\begin{array}{c}\text { t-test } \\
\text { Hyd coll } \\
(18)^{a}\end{array}}{3.76}$} & \multirow{2}{*}{$\frac{\begin{array}{c}\text { Zop coll } \\
(6)^{a}\end{array}}{1.44}$} \\
\hline & 1258 & (5.2) & 1152 & $(12.6)$ & 1188 & (20.9) & & & \\
\hline LT & 896 & (3.6) & 789 & $(9.7)$ & 870 & $(2.0)$ & $11.97^{* * *}$ & 2.13 & 4.48 \\
\hline L11 & 183.61 & (0.6) & 160 & (1.5) & 185 & (1.3) & $20.64^{* *}$ & 0.67 & $12.73^{* *}$ \\
\hline L10 & 124 & $(0.6)$ & 105 & (1.4) & 117 & (2.5) & $14.11^{* * *}$ & 3.35 & 4.34 \\
\hline W10 & 78 & (0.6) & 72 & (1.1) & 80 & (2.8) & $4.64^{* *}$ & 0.38 & 2.50 \\
\hline L9 & 143 & (1.2) & 117 & $(2.2)$ & 133 & (1.9) & $9.45^{* *}$ & 1.92 & 4.26 \\
\hline W9 & 78 & (3.4) & 66 & $(0.7)$ & 77 & (1.4) & $7.53^{* *}$ & 3.25 & $9.53^{* *}$ \\
\hline L8 & 129 & $(0.6)$ & 105 & (1.6) & 107 & $(0.4)$ & $14.18^{* *}$ & $8.49^{* *}$ & 0.71 \\
\hline W8 & 55 & $(0.4)$ & 51 & $(0.9)$ & 58 & $(0.5)$ & $4.31^{*}$ & 1.20 & 3.67 \\
\hline L7 & 178 & (1.0) & 144 & (2.6) & 155 & $(0.4)$ & $13.37^{* * *}$ & $6.84^{* *}$ & 1.92 \\
\hline W7 & 70 & $(0.4)$ & 62 & $(0.7)$ & 74 & $(0.3)$ & $6.74^{* *}$ & 1.39 & 4.74 \\
\hline $\mathrm{L} 6$ & 176 & (0.7) & 139 & $(1.0)$ & 143 & $(0.5)$ & $27.10^{* * *}$ & $16.10^{* * *}$ & 0.87 \\
\hline W6 & 53 & (1.1) & 45 & $(0.5)$ & 51 & $(0.3)$ & $9.08^{* *}$ & 1.09 & 3.46 \\
\hline L5 & 202 & $(1.2)$ & 167 & $(2.9)$ & 189 & $(0.5)$ & $12.66^{* * *}$ & $4.94^{* *}$ & 2.65 \\
\hline W5 & 51 & $(0.4)$ & 45 & $(0.6)$ & 51 & $(0.3)$ & $7.34^{* *}$ & 0.62 & 3.46 \\
\hline LE & 1826 & $(6.0)$ & 1641 & (18.1) & 1796 & $(28.8)$ & $12.60^{* * *}$ & 1.31 & 4.36 \\
\hline
\end{tabular}

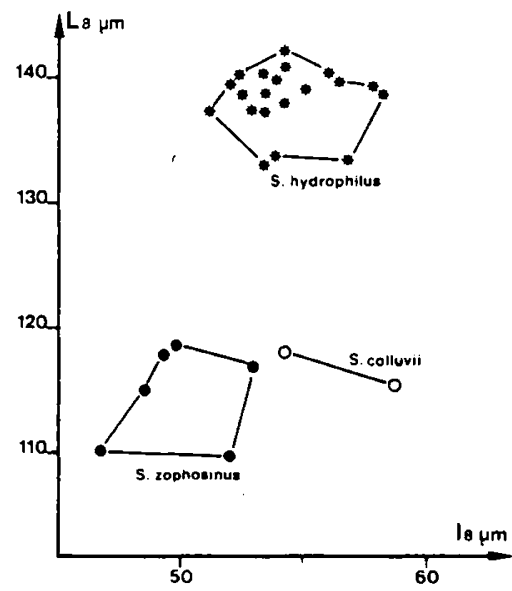

Fig 3. Separation of the populations according to the form of the 8th antennal segment $\left(\mathrm{L}_{8}\right.$ and $\left.\mathrm{W}_{8}\right)$.

Table IV reports, with Nei's distances, matrices of intra - and interspecific Euclidean distances on morphometric measurements. These data indicate that variations in morphology are more important between species than they are within each species. Figure 2 compares the results of the clustering based on allozyme 
(A, Nei's distances) and morphometric data (B, Euclidean distances). On the 2 bases, populations are clustered into 3 groups corresponding to the 3 species except for 1 population of $S$ hydrophilus which clusters with the group of $S$ colluvii populations. Nevertheless, the morphometric differences between the 3 allopatric species of Speonomus are discordant with the pattern displayed by electrophoretic dissimilarities. While on the molecular level, $S$ zophosinus has diverged less from $S$ hydrophilus than has $S$ colluvii, the morphological distance between these 2 species is greater (Euclidean distance: $263.09 \pm 5.68$ ). The marked dissimilarity of $S$ zophosinus is distinctly illustrated in a plot of the 3 species (conspecific populations pooled) on the lst 2 axes generated by the principal components' analysis (fig 4). The raw data, and the principal-component scores, are dominated by size: the lst principal component, explaining $82 \%$ of the variance, is associated with general size, with near-equal contributions from each character. The 3 species differ according to the general size of the individuals ( $S$ zophosinus individuals are the smallest and $S$ hydrophilus individuals the largest) and also according to the width of the 8 and 10 antennal segments (explained by the 2nd principal component).

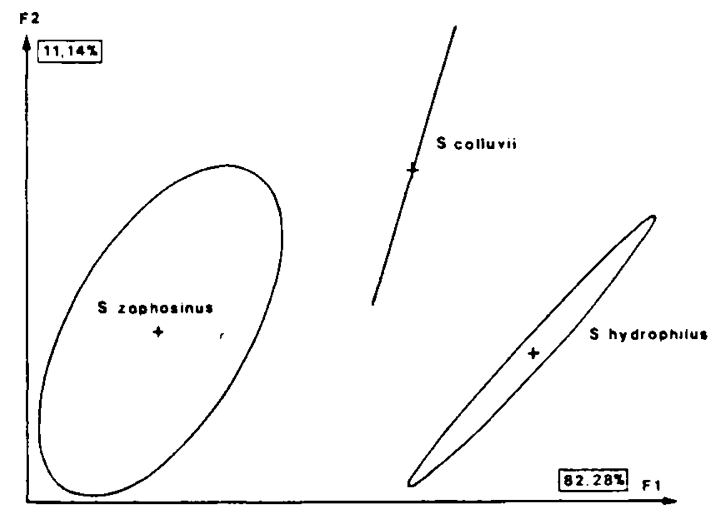

Fig 4. Principal components analysis of Speonomus populations based on morphometric data. Ellipses of equiprobability (95\%) are calculated according to Healy (1972).

\section{DISCUSSION}

In systematic studies, the choice of parameters may substantially influence the patterns observed. Since selection intensity is difficult to assess, consideration of more than a single class of traits can allow a more reasonable evaluation of the accuracy of systematic schemes. Several investigations have demonstrated that speciation can occur with little or no divergence at structural gene loci coding for allozymes: classes of genes other than those studied by electrophoresis (eg regulatory genes) might be involved in this process to a greater extent Ayala, 
1975; Wilson, 1976; Nevo, 1978). These species of Speonomus, show high degrees of genetic divergence; this genetic differentiation does not correspond to the differences in allele frequencies at the polymorphic loci but to the fixation of specific alleles. The greater part of the isozyme loci examined contain a large portion of their genetic diversity among species rather than within species (table III) despite the high level of within - population variation in some local populations of the 3 species (table IV). Electrophoresis usually underestimates the amount of variability in a species or population. Nevertheless, electromorphs can provide valuable taxonomic information and we found 32 and $50 \%$ of the loci studied to be diagnostic for any of the 3 sibling species of Speonomus. Moreover, an obvious disparity in size and behaviour during mating between the 3 species is visible. Ethological criteria have a great importance in speciation events. These Speonomus show within a single species a very low experimental frequency of matings (Crouau-Roy, 1986) in contrast to the 2 larval stages of $S$ delarouzei (Juberthie-Jupeau and Cazals, 1984). Thus, the occurrence of reproductive isolation between the 3 species cannot be shown. Nevertheless, during mating, constant and sometimes important differences appear between the species; they concern the length of mating, the different phases of the mating and the amplitude and frequency of abdominal movements of males during mating (Crouau-Roy, 1986). These different types of mating behaviour may enable one to discriminate the 3 species.

The consistent differences in electrophoretic differentiation, morphometric and behavioural differences, in conjunction with biogeographical distributions and ecological separation, offer convincing evidence of the separate species status of $S$ hydrophilus, $S$ zophosinus and $S$ colluvii. The results of this study applied to the taxonomic question are in complete agreement with the previously determined specific status of these beetles based on male genitalia (Jeannel, 1924), and on other morphological characters (Juberthie et al, 1980a, 1981; Delay et al, 1983).

What is the congruence between biochemical and morphological data? There is no congruence between the 2 sets of characters at the species level. Relative degrees of molecular divergence between the 3 species do not concur with degrees of morphological differentiation between the same species. The highest genetic identity values are found among the species $S$ hydrophilus and $S$ zophosinus. This is in contrast to morphological and biometrical analysis in which these 2 species exhibit the greatest difference (table IV; figs 2 and 3 ). $S$ colluvii and $S$ hydrophilus, morphologically more similar, show greater biochemical separation (fig 2). What factors would account for the observed discrepancy in degrees of differentiation? The genetic differences between these species, at structural genes measured by electrophoresis of the gene products, are the results of mutations accumulated since the time of divergence. This does not imply that they are critical in evolutionary terms. Electrophoresis can measure reduced gene flow or absence of gene flow, but cannot say anything about changes at the regulatory level, which may be very important in some speciation events (Wilson et al, 1974). Application of electrophoretic methods to taxonomic studies requires caution in interpretation of experimental data. It is not easy to assign limits to the electrophoretic variability disclosed experimentally in relation to biological criteria used in differentiation between species. The processes of evolution of different aspects, represented by different data sets (molecular, morphological, morphometrical and behavioural), 
may have been substantially uncoupled and proceeded independently or at different rates. For example, $S$ colluvii appears to have evolved biochemically much more than it has changed morphotypically, in particular from $S$ hydrophilus. The incongruence between extent of divergence in the 2 sets of characters could be the result of different sensitivities of each to different components of the environment. The 3 species studied here differ in their genetic structure (Crouau-Roy, 1989a, b) and in their ecological characteristics (Juberthie et al 1981; Crouau-Roy, 1986). The external morphometrical characteristics of Speonomus, traditionally used in systematic studies, could be under extensive selective pressures imposed by the local environment. Without heritability data, 1 suggestion is that the morphological variation has been more immediately shaped by ecological differences between the species. Further, an unknown proportion of the variation exhibited by many of these traits could be environmental rather than genetic in origin. The morphometrical data may reflect historical processes but are much more under the influence of differential selective pressures (micro - and macro-environmental influences) than the biochemical data.

\section{ACKNOWLEDGMENTS}

I would particularly like to thank TC Kane for helpful discussions and his valuable criticism of the manuscript. I am grateful to D D'Hulst for the computer program of the genetic analysis, to C Juberthie and B Delay for valuable discussions and assistance in the field collecting, to C Ferre for technical assistance and to F Boineau for typing the manuscript.

\section{REFERENCES}

Allegrucci G, Cesaroni D, Sbordoni V (1987) Adaptation and speciation of Dolichopoda cave crickets: geographic variation of morphometric indices and allozyme frequencies. Biol J Linn Soc 31, 151-160

Avise JC (1974) Systematic value of electrophoretic data. Syst Zool 23, 465-481

Ayala FJ (1975) Genetic differentiation during the speciation process. In: Evolutionary Biology (Dobzhansky T, Hecht M, Steere W, eds) Plenum Press 8, 1-78

Berlocher SH, Bush GL (1982) An electrophoretic analysis of Rhagoletis (Diptera Tephritidae) phylogeny. Syst Zool 31, 136-155

Crouau-Roy B (1986) Structure génétique des populations et des espèces chez des Coléoptères troglobies (Speonomus). Contribution à l'étude des mécanismes de la spéciation. Thèse d'Etat - Montpellier II, 1-300

Crouau-Roy B (1988) Genetic structure of cave-dwelling beetles populations: significant deficiencies of heterozygotes. Heredity $60,321-327$

Crouau-Roy B (1989a) Genetic population structure in a troglobitic beetle (Speonomus zophosinus). Genetica $78,13-20$ 
Crouau-Roy B (1989b) Population studies on an endemic troglobitic beetle: geographical patterns of genetic variation, gene flow and genetic structure compared with morphometric data. Genetics 121, 571-582

Delay B, Juberthie C, Ruffat G (1983) Description de Speonomus colluvii du milieu souterrain superficiel des Pyrénées ariégeoises. Mém Biospéol X, 249-256

Deleurance-Glacon S (1963) Recherches sur les Coléoptères troglobies de la sousfamille des Bathysciinae. Ann Sci Nat Zool 5, 1-172

Durand JL, Juberthie-Jupeau L (1980) Etude cytogénétique de deux espèces de Speonomus (Coléoptères, Bathysciinae). Mem Biospéol 7, 267-271

Gorman GC, Kim YJ (1976) Anolis lizards of the Eastern Caribbean: a case study in evolution. II. Genetic relationships and genetic variability of the bimaculatus group. Syst Zool 25, 62-77

Healy MJ (1972) Drawing a probability ellipse. J Roy Stat Soc series C 21, 202-204

Jeannel R (1924) Monographie des Bathysciinae. Biospeologica. L Arch Zool Exp Gén 63, 1-436

Juberthie C, Delay B, Ruffat G (1980a) Variations biométriques entre différentes populations de Speonomus hydrophilus en relation avec leur situation géographique. Mém Biospéol VII, 353-364

Juberthie C, Delay B, Bouillon M (1980b) Sur l'existence d'un milieu souterrain superficiel en zone non calcaire. CR Acad Sci 290, 49-52

Juberthie C, Delay B, Durand J, Juberthie-Jupeau L, Bouillon M, Ruffat G (1981) Etude écologique, biométrique, morphologique et biologique de Speonomus zophosinus. Mém Biospéol VIII, 83-102

Juberthie-Jupeau L, Cazals M (1984) Modalités de l'accouplement dans différentes populations du complexe Speonomus delarouzeei. Coléoptères Bathysciinae souterrains. Mém Biospéol XI, 165-172

Lessios HA (1981) Divergence in allopatry molecular and morphological differentiation between sea Urchins separated by the Isthmus of Panama. Evolution 35, 618-634

Lewontin RC (1984) Detecting population differences in quantitative characters as opposed to gene frequencies, Am Nat 123, 115-124

Nei M (1972) Genetic distance between populations. Am Nat 106, 283-292

Nei $M$ (1977) Statistics and analysis of gene diversity in subdivided populations. Ann Hum Genet (Lond) 41, 225-233

Nei M (1978) Estimation of average heterozygosity and genetic distance from a small number of individuals. Genetics $89,583-590$

Nei M (1986) Definition and estimation of fixation indices. Evolution 40, 643-647

Nei M, Roychoudhury AK (1974) Sampling variances of heterozygosity and genetic distance. Genetics 76, 379-390

Nevo E (1978) Genetic variation in natural populations. Pattern and theory. Theor Pop Biol 13, 121-177 
Schnell GD, Kennedy NL, Best TL (1978) Interspecific morphological variation in Kangaroo rats (Dipodomys). Degrees of concordance with genic variation. Syst Zool 27, 34-48

Sene FM, Carson HL (1977) Genetic variation in Hawaiian Drosophila IV, Allozymic similarity between $D$ silvestris and $D$ heteroneura from islands of Hawaii. Genetics 86, 187-198

Sneath PHA, Sokal RR (1973) Numerical Taxonomy. WH Freeman and Co, San Francisco

Sokal RR, Rohlf R (1969) Biometry: the principles and practice of statistics in Biological research. WH Freeman and Co, San Francisco

Turner JRG, Johnson MS, Eanes WF (1979) Contrasted modes of evolution in the same genome: allozymes and adaptive change in Heliconius. Proc Natl Acad Sci USA 76, 1924-1928

Wilson AC (1976) Gene regulation in evolution, In: Molecular Evolution (Ayala FJ, ed) Sinauer, Sunderland, Mass, 225-234

Wilson AC, Maxson LR, Sarich VM (1974) Two types of molecular evolution. Evidence from studies of interspecific hybridization. Proc Natl Acad Sci USA 71, 2843-2847

Workman PL, Niswander JD (1970) Population studies on south-western Indian Tribes. II. Local genetic differentiation in the Papago. Am J Hum Genet 22, 24-29

Wright S (1965) The interpretation of population structure by $\mathrm{F}$ statistics with special regard to systems of mating. Evolution 19, 395-420 